\title{
Risk Prediction Models for Hypertensive Disorders of Pregnancy: Role of 12-Lead Electrocardiography
}

\author{
Fabio Angeli ${ }^{1}$, Enrica Angeli ${ }^{2}$, Antonella D’Antonio ${ }^{1}$, Cristina Poltronieri ${ }^{1}$, Giuseppe Ambrosio ${ }^{1}$ \\ ${ }^{1}$ Division of Cardiology, University of Perugia School of Medicine, Perugia, Italy \\ ${ }^{2}$ Division of Gynecology and Obstetrics, Hospital San G. Battista, Foligno, Italy
}

SUMMARY

Hypertensive disorders represent the most common medical complications of pregnancy, affecting 6 to 8 percent of gestations. They may lead to severe maternal and fetal complications.

Several observational studies have highlighted that weight, systolic and diastolic blood pressure, obtained at antenatal visit prior to 16 weeks, may be suitable to stratify the risk of developing hypertensive disorders during pregnancy.

Recently, however, other markers have been proposed as potential predictors of hypertensive disorders during pregnancy. In this context, some electrocardiographic changes have shown significant power in refining risk stratification. Specifically, changes during pregnancy in QT interval and $\mathrm{P}$ wave morphology improved the accuracy of multivariable models for the prediction of hypertensive disorders. In particular, the presence of left atrial abnormalities at ECG seems to be associated with a marked increase in the risk of developing hypertensive disorders, and when included in a multivariable model taking into account some maternal features, it may discriminate between women who will develop hypertensive disorders during pregnancy and women who will remain normotensive. This prediction model was also able to identify pregnant women at increased risk for the occurrence of fetal/neonatal complications.

The aim of the present overview is to discuss the available data supporting the evidence that specific ECG patterns occurring early in pregnancy may have clinical relevance for risk prediction of hypertensive disorders.

Key words: hypertensive disorders, pregnancy, risk prediction models, eclampsia, blood pressure, electrocardiography 


\section{INTRODUCTION}

Hypertensive disorders represent the most common medical complications of pregnancy, affecting 6 to 8 percent of gestations (1-3). They may lead to severe maternal complications, including eclamptic seizures, intracerebral hemorrhage, pulmonary edema, acute renal failure, and liver dysfunction $(4,5)$.

Hypertensive disorders are also an important cause of perinatal morbidity and mortality contributing to fetal complications including placental abruption intrauterine growth restriction, premature delivery, and intrauterine fetal death $(1-3,5)$. Observational evidence supporting the worse prognosis associated to hypertensive disorders in pregnancy provide a strong basis for developing risk prediction models to identify women whose gestations may be considered at high risk for hypertensive disorders (6).

To date, several risk factors for development of hypertensive disorders in pregnancy have been described, generally with relative risks of 1.5 to 9.7 in meta-analyses and systematic reviews (7).

Results of several observational studies highlighted that weight, systolic and diastolic BP may be suitable to stratify the risk of becoming hypertensive during pregnancy $(4,8)$.

More recently, some circulating and urinary markers have been proposed as potential predictors of hypertensive disorders during pregnancy. They include plasminogen activator inhibitor, soluble fmslike tyrosine kinase, placental growth factor, von Willenbrand factor, leptin, C-reactive protein, serum uric acid and urinary albumin fragments (8).

However, early prediction of hypertensive disorders in pregnancy remains problematic, because severe forms (i.e. "pre-eclampsia" and eclampsia) are etiologically complex and heterogeneous (4). Furthermore, systematic reviews and meta-analyses suggest that any single test may lack predictive value or practical utility to be applied at large (8). Consequently, several investigators have used a combination of different tests to predict hypertensive disorders, and interest has grown in the development of multivariable models that include both clinical and laboratory/instrumental predictors, available at booking and thereafter in pregnancy (8).

In this context, some collaborative studies between gynecologists, internists and cardiologists (9) used the combinations of different tests to develop multivariable risk models for the prediction of hypertensive disorders during pregnancy. The use of multiple markers in a screening approach may reflects different aspects of the hypertensive disease process and increases the specificity and sensitivity of the screening $(8,9)$. In particular, some studies evaluated the additive value of electrocardiography (ECG) and its combinations with maternal factors and biochemical markers to refine risk stratification for hypertensive disorders in pregnancy (10-13).

The main aim of this review is to specifically discuss the available data supporting the concept that some ECG patterns occurring early in pregnancy may have clinical relevance for the risk prediction of hypertensive disorders. To this purpose, published literature was retrieved through searches of Medline, CINAHL, and The Cochrane Library using appropriate controlled vocabulary (pregnancy, hypertension, "preeclampsia") and key words (diagnosis, evaluation, prediction, prevention, prognosis, electrocardiography) $(14,15)$.

\section{CLASSIFICATION OF HYPERTENSIVE DISORDERS}

Hypertension in pregnancy is defined by office systolic blood pressure (BP) $\geq 140 \mathrm{mmHg}$ and/or diastolic $\mathrm{BP} \geq 90 \mathrm{mmHg}$. Hypertensive disorders are generally classified into four categories, as recommended by the National High Blood Pressure Education Program Working Group on High Blood Pressure in Pregnancy (6): (1) chronic hypertension; (2) "pre-eclampsia"-eclampsia; (3) "pre-eclampsia" superimposed on chronic hypertension; and (4) gestational hypertension (transient hypertension of pregnancy or chronic hypertension identified in the latter half of pregnancy).

Just recently, the Canadian Hypertensive Disorders of Pregnancy Working Group (5) reviewed the approach to the diagnosis, evaluation, and treatment of the hypertensive disorders of pregnancy suggesting a new classification. According to these guidelines (5), hypertensive disorders during pregnancy are classified into the following categories:

1. pre-existing or chronic hypertension (hypertension that was present before pregnancy or that develops at $<20^{\text {th }}$ week of gestation);

2. gestational hypertension (hypertension that develops for the first time at $\geq 20^{\text {th }}$ week of gestation; this definition is preferred over the older term of pregnancy-induced hypertension); 
3. pre-eclampsia - eclampsia;

4. other hypertensive effects (including transient hypertensive effect, white-coat hypertensive effect and masked hypertensive effect).

For pre-existing and gestational hypertension, there are two subgroups: (a) with comorbid conditions that mandate tighter BP control as outside pregnancy (to protect end-organ function), and (b) with "pre-eclampsia" (given its substantial maternal and perinatal risks) (5).

\section{CARDIOVASCULAR ADAPTATIONS IN PREGNANCY}

Pregnancy is a dynamic process associated with significant physiological changes in the cardiovascular system. These changes are mechanisms that the body has adapted to meet the increased metabolic demands of the mother and fetus and to ensure adequate uteroplacental circulation for fetal growth and development $(16,17)$. The knowledge of cardiovascular adaptations in pregnancy is required to correctly interpret ECG in pregnant women, and to predict the effects of pregnancy on the woman.

The major hemodynamic changes induced by pregnancy include an increase in cardiac output, sodium and water retention leading to blood volume expansion, and reductions in systemic vascular resistance and systemic BP $(16,17)$.

Cardiac output increases throughout pregnancy $(16,17)$. The sharpest rise in cardiac output occurs by the beginning of the first trimester, and there is a continued increase into the second trimester. By 24 weeks, the increase in cardiac output can be up to $45 \%$ in a normal, singleton pregnancy. Cardiac output early in gestation is thought to be mediated by the increase in stroke volume, whereas later in gestation, the increase is attributable to heart rate $(16,17)$.

Stroke volume increases gradually in pregnancy until the end of the second trimester and then remains constant or decreases late in pregnancy $(16,17)$. There is a decrease in arterial pressures, including systolic BP, diastolic $\mathrm{BP}$, and mean arterial pressure during pregnancy (17). In particular, diastolic BP and mean arterial pressure decrease more than systolic BP during the pregnancy. Arterial pressures decrease to a nadir during the second trimester (dropping $10 \mathrm{~mm} \mathrm{Hg}$ below baseline), but the majority of the decrease occurs early in pregnancy (6- to 8-week gestational age) compared with preconception values. Arterial pressures begin to increase during the third trimester and return close to preconception levels postpartum (17).

Heart rate also increases during normal pregnancy. Unlike many of the prior parameters that reach their maximum change during the second trimester, heart rate increases progressively throughout the pregnancy, reaching a maximum heart rate in the third trimester. The overall change in heart rate reaches a $20 \%$ to $25 \%$ increase over baseline (17).

During pregnancy, there is a $30-50 \%$ increase in extracellular fluids and a $30-40 \%$ increase in plasma volume. The driving force for the increase in extracellular volume is a decrease in the systemic vascular resistance, as reflected by a fall in the systolic and diastolic BP in early gestation (17). In this context, vasodilating factors such as nitric oxide (NO) may play an important role in the decrease in vascular resistance (18). The generalized vasodilation results in a compensatory activation of the renin-angiotensin system (RAS), leading to water and sodium retention (19). Furthermore, renal blood flow and glomerular filtration rate markedly increase during pregnancy, and peak at approximately $50 \%$ above non-pregnant levels in the second trimester (20).

\section{NORMAL ECG IN PREGNANCY}

Although little is known about the characteristics of the 12-lead ECG in pregnancy, there is evidence from previous studies to suggest that some ECG parameters are altered by the pregnant state and the known cardiovascular adaptations to pregnancy represent potential mechanisms by which these alterations may arise (9).

Despite the mixed nature of the evidence, there is indication that pregnancy affects the ECG at some time point and that there is restoration of these changes following delivery (21-29). Heart rate (HR) increases progressively throughout pregnancy, reaching a peak during the third trimester. This increase in HR is related to hormonal factors in early stages of pregnancy and later to increased left atrial diameter and sympathetic activation (22).

Particular attention has been paid to the QRS axis and its direction of shift (if any) during pregnancy. Studies have produced conflicting results with regards to the direction of this shift and its time course during gestation. However, a leftward deviation of the mean QRS axis during the second and third trimesters of 
pregnancy and then rightward before delivery is observed in the majority of women (21-29).

PR interval exhibits a significant reduction in the mean values during pregnancy, while the QRS amplitude generally increases slightly in the late pregnancy (but without a clear evidence of left ventricular hypertrophy).

Flat or inverted $\mathrm{T}$ wave in leads $\mathrm{D}_{\mathrm{III}}, \mathrm{V}_{1}$ and $\mathrm{V}_{2}$ may be documented during pregnancy and $\mathrm{Q}$ waves in leads Dill and aVF are common (21-29).

No clinically significant changes occur in other ECG intervals (including QT interval) or cardiac rhythm (21-29).

\section{ECG CHANGES AND RISK OF HYPERTENSIVE DISORDERS}

Some observations suggested that abnormal ECG patterns maybe associated with increased risk of hypertensive disorders of pregnancy $(8,10,22)$. Specifically, hypertensive disorders of pregnancy may be associated with changes in P-wave morphology and QT interval (22).

QT interval. The QT interval is a measure of the time between the start of the $Q$ wave and the end of the $\mathrm{T}$ wave in the heart's electrical cycle. The QT interval represents electrical depolarization and repolarization of the ventricles. QT interval seems to be unaffected by normal pregnancy (21). Conversely, pregnancies that develop hypertensive disorders seem to be accompanied by changes in ventricular repolarization that may precede clinical symptoms (30). Baumert and co-workers (30) quantified longitudinal changes in ventricular repolarization during pregnancy. Monthly ECGs were recorded in 32 pregnant women with normal uterine perfusion and 32 pregnant women with abnormal perfusion, starting from the $20^{\text {th }}$ week of gestation until 3 days postpartum. Ventricular repolarization was assessed through various QT interval variability and HR adaptation measures. Among pregnancies with abnormal uterine perfusion, 15 pregnancy outcomes were normal, but 17 pregnancies developed "preeclampsia" and/or small-for-gestational-age infants. In pregnancies with normal perfusion, the QT(c) interval was unaltered, but the QT interval-HR regression residual was higher compared with those of a control group of 10 healthy non-pregnant women. Interestingly, pregnancies with abnormal uterine perfusion that developed pathological outcomes showed significantly smaller QT interval-heart rate regression residuals and a trend towards shorter QT(c) intervals compared with pregnant women with normal perfusion (30).

In a prospective study by Isezuo and Ekele (31), the QT interval corrected for HR (QTc), serum calcium, magnesium and potassium were compared among 30 intrapartum eclamptics and 30 age-, parity- and gestational age-matched women with uncomplicated pregnancy. Briefly, they documented that BP was significantly higher among patients than controls $(\mathrm{p}<0.05)$, and the corresponding QTc values were 390572 and 390-460, respectively. Compared to the controls, patients had significantly higher mean heart rate and higher QTc (470.4 vs 436.3, p<0.05) (31).

Raffaelli and co-workers (32) investigated the effect of pre-eclampsia on electrical cardiac activity and demonstrated that pregnancies complicated by preeclampsia had a significant alteration of ventricular repolarization. They recruited 76 women affected by pre-eclampsia and a control group of pregnant women without cardiovascular disease or gestational hypertension. A standard 12-lead ECG was performed on all patients prior to delivery. Routine evaluation of the ECGs in both groups was mostly non-pathological. However, pre-eclamptic women showed a lower HR (77.4 \pm 14.3 vs $81.6 \pm 11.0 \mathrm{bpm}$; $\mathrm{p}=0.005)$, a longer mean QTc interval (442.7 \pm 26.7 vs $423.7 \pm 20.7$ msec; $\mathrm{p}<0.001)$, and a higher QT dispersion (24.0 vs $22.0 \mathrm{msec} ; \mathrm{p}<0.001$ ) than the control group (32). In this context, it is worth to mention that QT dispersion is an indicator of inhomogeneity in ventricular activity and its prolongation is correlated with an increased incidence of ventricular arrhythmias and is a predictor of all-cause mortality (33). Thus, prolonged QT dispersion could explain the increased incidence of serious ventricular arrhythmias and adverse outcomes in pregnant women with pre-eclampsia (32).

Interestingly, assessing the acute cardiac effects of pre-eclampsia on ventricular repolarization, Raffaelli and co-workers (32) also documented that treatment with $\mathrm{MgSO} 4$ was an independent predictor of prolonged QT interval $(\mathrm{p}<0.001)$. Although intriguing, the lack of a formal interaction test between measures of ventricular repolarization and $\mathrm{MgSO} 4$ administration in that study does not support the hypothesis that alterations in the QT interval precedes clinical manifestations of eclampsia (i.e. prolonged QTc interval might be only the result of high dose administration of MgSO4). Thus, the notion that increased ventricular repolarization heterogeneity (as documented by higher values of QT dispersion) is a spontaneous high risk 
feature of pre-eclampsia for the development of adverse events remains questionable (22).

$\mathbf{P}$ wave. In the analysis by Raffaelli and coworkers, authors also documented that P-wave duration was significantly longer in the pre-eclamptic women than in the control group (32). This finding is consistent with a previous prospective screening study from our group which investigated the potential additive role of standard ECG in the identification of pregnant women at increased risk for hypertensive complications $(8,10)$. Specifically, at the first antenatal visit, 12-lead ECG was recorded and the following ECG parameters were analyzed: HR, QRS duration, QTc interval, Cornell voltage, ST-T abnormalities, and left atrial abnormality. The QT interval was corrected by HR according to Bazett's formula (34). The Cornell voltage was computed as the sum of the amplitudes of $S$ wave in $V_{3}$ and $R$ wave in aVL (35). ST-T changes were analyzed according to the Minnesota Coding (36). Criteria for ST-T changes were any of the following: (1) coexistence, in any leads I, II, aVL or V3-V6 of ST-segment horizontal or downward sloping depression $\geq 0.05 \mathrm{mV}$ (code 4-1 or 4-2) plus Twave asymmetric inversion (code 5-1 or 5-2); (2) ST-J depression $<0.05 \mathrm{mV}$ with ST-segment downward sloping and segment or T-wave nadir $>0.05 \mathrm{mV}$ below P-R baseline, in any of leads I, II, aVL or V2-V6 (code 43); (3) ST-J depression of $\geq 0.10 \mathrm{mV}$ and ST-segment upward sloping or U-shaped, in any of leads I, II, aVL or V2-V6 (code 4-4); (4) T-wave amplitude zero (flat), negative or diphasic (negative-positive type only) with < $0.10 \mathrm{mV}$ negative phase in lead I, II, V3-V6, or in lead aVL when R-wave amplitude is $\geq 0.5 \mathrm{mV}$ (code 5-3): (5) $\mathrm{T}$-wave amplitude positive and $\mathrm{T}$ - to $\mathrm{R}$-wave amplitude ratio $<1: 20$ in any of leads I, II, aVL or V3-V6 when Rwave amplitude in the corresponding leads is $\geq 1.0 \mathrm{mV}$ (code 5-4).

P wave morphology was analyzed in all of standard ECG leads. The criteria used for the diagnosis of $\mathrm{P}$ wave abnormality in lead $\mathrm{V}_{1}$ were: (1) bipeak interval in deeply notched $P$ wave with (2) terminal forces equal to or more negative than $-0.04 \mathrm{mmsec}$, as obtained from the product of the depth of the terminal negative deflection and its duration $(37,38)$. The following other criteria were used for the diagnosis of LA abnormality in any other lead than $V_{1}$ : (1) bipeak interval in deeply notched $\mathrm{P}$ waves wider than $0,04 \mathrm{sec}$ or (2) P-wave/PR-segment ratio greater than 1.6 or (3) P wave higher than $3 \mathrm{~mm}$ or (4) total $\mathrm{P}$ wave duration greater than $0.11 \mathrm{sec}(37,38)$.
The primary outcome of the study was the development of gestational hypertension, pre-eclampsia and eclampsia. The secondary outcome was a composite measure of hypertensive disorders and other pregnancy complications including fetal growth restriction, HELLP (hemolysis, elevated liver enzymes, low platelets) syndrome, placental abruption, stillbirth, premature delivery and neonatal death $(6,39,40)$. Overall, 221 pregnant women were included in the final analysis. The primary outcome of hypertensive disorders occurred in 28 women, while the secondary composite outcome was recorded in 43 women.

At entry, women who subsequently developed hypertensive disorders differed under some aspects from those who did not experience these events: weight, body mass index (BMI) and BP were higher in women with hypertensive diseases than in those without (all $\mathrm{p}<0.05)$. Notably, left atrial abnormality in lead $\mathrm{V}_{1}$ was also more prevalent in women with hypertension disorders $(p=0.002)$. Age, laboratory tests, HR and other ECG parameters including left atrial abnormality observed in other leads than Viand QRS/ST-T changes did not differ between the two groups. Compared with pregnant women with normal $\mathrm{P}$ wave at ECG, women with left atrial abnormality in lead $\mathrm{V}_{1}$ had similar mean arterial pressure (MAP, 85.6 vs $85.1 \mathrm{mmHg}$, $\mathrm{p}=0.661$ ), and prevalence of left atrial abnormality did not show any association with baseline BP values.

To develop a multivariable model for risk prediction of hypertensive disorders, we tested several potential predictors including age (years), height $(\mathrm{cm})$, weight $(\mathrm{Kg})$, BMI $\left(\mathrm{Kg} / \mathrm{m}^{2}\right)$, previous use of estrogens (yes, no), systolic and diastolic BP (mmHg), MAP $(\mathrm{mmHg}), \mathrm{PP}(\mathrm{mmHg})$, haemoglobin $(\mathrm{g} / \mathrm{dl})$, fibrinogen $(\mathrm{mg} / \mathrm{dl})$, sodium $(\mathrm{mEq} / \mathrm{L})$, potassium $(\mathrm{mEq} / \mathrm{L})$, serum creatinine $(\mathrm{mg} / \mathrm{dl})$, serum glucose $(\mathrm{mg} / \mathrm{dl})$ smoking habit (non-smoker, current smoker), HR (bpm), QTc (msec), Cornell voltage $(\mathrm{mm})$, ST-T changes (yes, no) and LA abnormality (yes, no). In univariate models, only weight, $\mathrm{BMI}$, systolic and diastolic BP, MAP, pulse pressure and left atrial abnormality in lead $\mathrm{V}_{1}$ or in any lead were predictors for hypertensive disorders (all $\mathrm{p}<0.05$; Figure). Other tested parameters did not achieve statistical significance (all $p>0.05$ ). Building a multivariable model according to standardized methods, only MAP and left atrial abnormality in lead $V_{1}$ were independent predictors of hypertensive disorders. Other covariates tested did not achieve statistical significance and they were not included in the final model. 

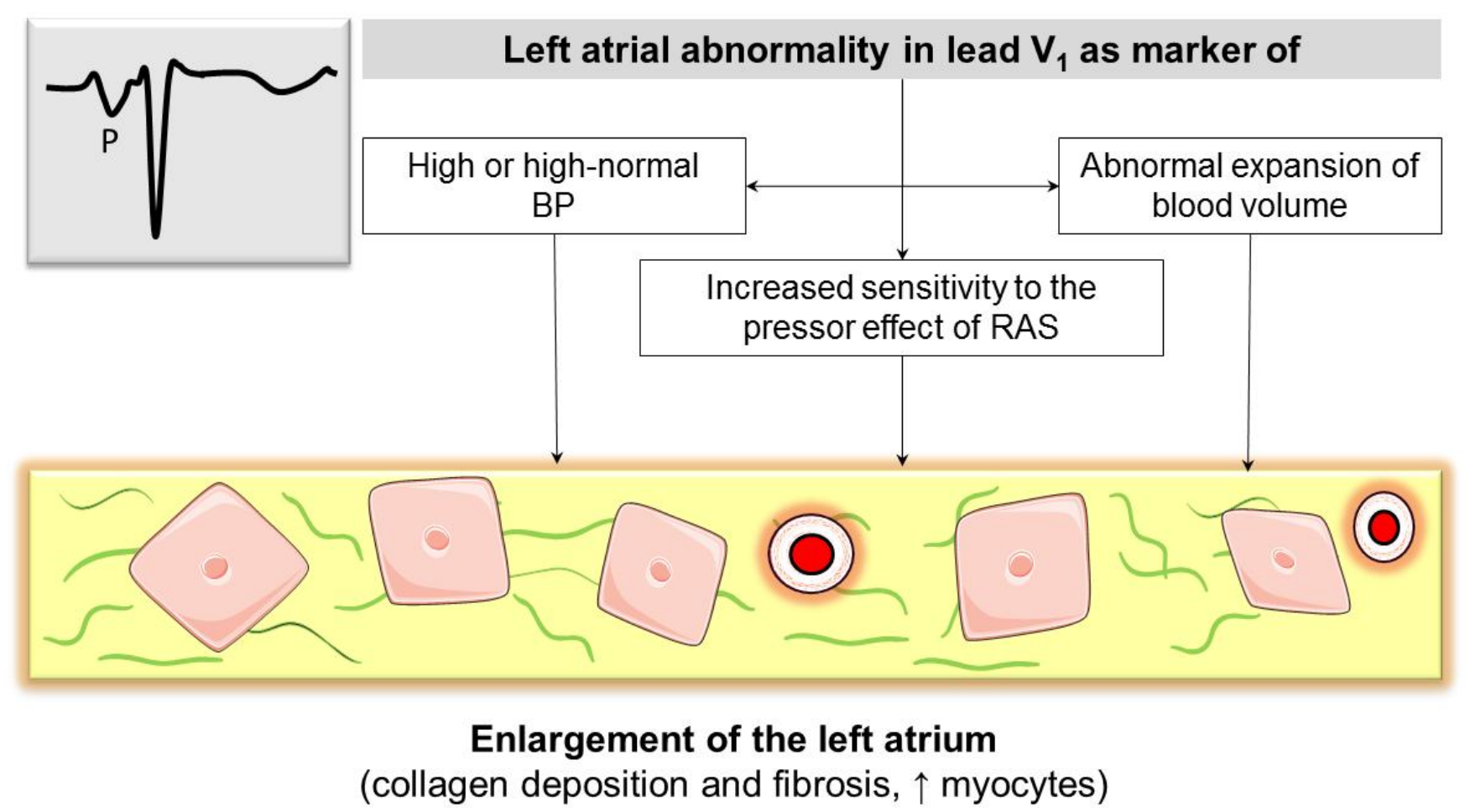

Figure. Mechanisms linking the left atrial abnormality detected in pregnancy by 12-lead ECG and development of hypertensive complications in pregnancy. From ref. $(4,8,10,22)$.

Using this model, the presence of left atrial abnormality in lead $\mathrm{V}_{1}$ was associated to a 4-fold increased risk of developing hypertensive disorders (OR: 4.35; 95\% confidence interval [CI]: 1.84-10.31; $\mathrm{p}=0.001$ ). The calibration of the final model was good, confirmed by a non-significant Hosmer-Lemeshow test $(p=0.346)$. Moreover, the final model discriminated well between women who developed hypertensive disorders and women who remained normotensive during pregnancy, with an AUC of 0.754 (95\% CI: 0.667-0.841; $\mathrm{p}<0.0001)(10)$.

Although the potential link between left atrial abnormality detected early in pregnancy by ECG and development of hypertensive disorders remains elusive, some possible mechanisms (as depicted in the Figure) are supported by experimental models $(8,10,22)$. Notably, abnormality of P-wave morphology in lead $\mathrm{V}_{1}$ tested as predictor of hypertensive disorders during pregnancy (10) in our analysis is commonly used as an ECG sign of left atrial enlargement (8). Left atrial enlargement is very common in hypertensive subjects and may be an early sign of heart involvement in arterial systemic hypertension $(41,42)$.

Many clinical studies in hypertensive patients found a significant relation between BP overload and left atrial abnormalities (41-45). The lack of association between left atrial enlargement at ECG and BP values observed in our study (10) supports the poor ability of casual BP measurements obtained at the time of the first visit to the hospital to detect the real BP load of pregnant women. In other words, the tendency of BP to decrease in early pregnancy (46) may mask the real load of women with abnormal BP before pregnancy. Thus, the presence of an abnormal $\mathrm{P}$ wave in the early phase of gestation may be considered as a marker of masked hypertension or high or high-normal BP values.

Other potential explanations for the association between left atrial enlargement and subsequent development of hypertension during pregnancy may be postulated considering some data obtained from experimental models of eclamptic and pre-eclamptic disease $(8,10,22)$.

Expansion of blood volume directly affects left atrial pressure and dimensions (47) with a consequent increased release of atrial natriuretic peptide (ANP) (48). In pregnancy, the major hemodynamic changes during pregnancy include an increase in cardiac output, sodium and water retention leading to blood volume expansion. These changes begin early in pregnancy, reach their peak during the second trimester and then remain relatively constant until delivery (49, 50). In uncomplicated pregnancy, plasma renin activity tends to be increased, and ANP levels are slightly reduced (51, 52). In contrast, plasma ANP concentrations have been 
extensively reported as increased in patients with hypertensive disorders during pregnancy, especially in patients with severe pre-eclampsia (53-55). In this context, the detection of left atrial enlargement may be a marker of an abnormal expansion of blood volume in the early phase of pregnancy which may affect left atrial morphology (47) and it may predispose to the development of hypertensive disease.

Other changes during pregnancy include early renal vasodilatation and hyperfiltration, and marked stimulation of the all measured elements of RAS (Figure) $(40,56-58)$. In patients developing pre-eclampsia there is a loss of the normal pregnancy-associated refractoriness to pressor agents, and sensitivity to infused Angiotensin II increases weeks before overt disease. Explanations for the increased reactivity to Angiotensin II include upregulation of receptor sensitivity, synergy with circulating autoantibodies agonistic to the angiotensin type 1 receptor and decreases in the level of circulating Angiotensin 1-7 (59-67).

Since experimental approaches have been confirmed that the local RAAS in the heart could trigger development of cardiac hypertrophy and massive enlargement of the atria caused by myocyte hyperplasia, an increased sensitivity to the pressor effect of the RAS (Figure) in some women may be involved in the development of ECG signs of left atrial enlargement and predisposes to the development of hypertensive disorders.

\section{CONCLUSIONS}

Over the last few years, epidemiological data identified several risk factors for the development of hypertensive disorders in pregnancy. Recent surveys on large proportion of healthy nulliparous pregnant women analyzed the potential role of maternal demographics and clinical characteristics commonly recognized during pregnancy as predictors of gestational hypertension. Results showed that weight, systolic and diastolic BP obtained at the antenatal booking visit may be suitable to stratify the risk of becoming hypertensive during gestation $(4,8,10,22$,$) .$

In addition, history of pre-eclampsia, pre-existing diabetes, multiple pregnancy, nulliparity, family history of pre-eclampsia and age $\geq 40$ are commonly associated to an increased risk for the development of hypertensive disorders $(5,7,13$,). The risk of pre-eclampsia is also increased with pre-existing hypertension and renal disease, a pregnancy interval of $\geq 10$ years, and confirmed proteinuria $(5,7,13$,).

Just recently, several clinical ultrasonographic, and laboratory parameters have been explored during early pregnancy as tools for prediction who will later develop hypertensive disorders; these include uterine artery Doppler studies, measurement of angiogenic factors, provocative biophysical tests and urinary proteomics (8). Nevertheless, no single test is sufficiently reliable and accurate to be applied at large and there is no clinically useful prediction models for the development of hypertensive disorders (8).

In the last few years, clinicians have been encouraged to participate in clinical research and some collaborative studies between gynecologists, internists and cardiologists (9) tried to develop multivariable risk prediction models using the combinations of different tests. In this regard, some reports suggested the additive value of some ECG parameters to refine risk stratification for hypertensive disorders in pregnancy $(8$, 15-17). Specifically, changes during pregnancy in QT interval and $\mathrm{P}$ wave morphology have been tested suggesting that their combinations with maternal risk markers might improve the accuracy of multivariable predictive models for the prediction of hypertensive disorders of pregnancy.

\section{Conflicts of Interest}

None of the authors of this study has financial or other reasons that could lead to a conflict of interest. 


\section{References}

1. Berg CJ, Chang J, Callaghan WM, Whitehead SJ. Pregnancy-related mortality in the united states, 1991-1997. ObstetGynecol 2003; 101: 289-96. http://dx.doi.org/10.1097/00006250-20030200000015

2. Chang J, Elam-Evans LD, Berg CJ et al.Pregnancy-related mortality surveillance-united states, 1991--1999. MMWR Surveill Summ 2003; 52: 1-8.

3. MacKay AP, Berg CJ, Duran $\mathrm{C}$ et al. An assessment of pregnancy-related mortality in the united states. Paediatr Perinat Epidemiol 2005; 19: 206-14.

http://dx.doi.org/10.1111/j.1365-3016.2005.00653.x

4. Angeli F, Angeli E, Verdecchia P. Novel electrocardiographic patterns for the prediction of hypertensive disorders of pregnancy-from pathophysiology to practical implications. Int J Mol Sci 2015; 16: 18454-73.

http://dx.doi.org/10.3390/ijms160818454

5. Mage, LA, Pels A, Helewa M et al. Hypertension Guideline, C. Diagnosis, evaluation, and management of the hypertensive disorders of pregnancy: Executive summary. J Obstet Gynaecol Can 2014; 36: 416-38.

http://dx.doi.org/10.1016/S1701-2163(15)30588-0

6. Report of the national high blood pressure education program working group on high blood pressure in pregnancy. Am J ObstetGynecol 2000; 183: S1-S22.

http://dx.doi.org/10.1067/mob.2000.107928

7. .Milne F, Redman C, Walker J et al. The preeclampsia community guideline (precog): How to screen for and detect onset of pre-eclampsia in the community. BMJ 2005; 330: 576-80.

http://dx.doi.org/10.1136/bmj.330.7491.576

8. Angeli F, Angeli E, Reboldi G, Verdecchia P. Hypertensive disorders during pregnancy: Clinical applicability of risk prediction models. J Hypertens 2011; 29: 2320-3.
http://dx.doi.org/10.1097/HJH.0b013e32834d6ed7

9. Nijdam ME, Janssen KJ, Moons KG, et al. Prediction model for hypertension in pregnancy in nulliparous women using information obtained at the first antenatal visit. J Hypertens 2010; 28: 119-26.

http://dx.doi.org/10.1097/HJH.0b013e32833191b0

10. Angeli E, Verdecchia P, Narducci P, Angeli F. Additive value of standard ecg for the risk prediction of hypertensive disorders during pregnancy. Hypertens Res 2011; 34: 707-13. http://dx.doi.org/10.1038/hr.2011.12

11. Benedetto C,Valensise $\mathrm{H}$, Marozio L et al.. A two-stage screening test for pregnancy-induced hypertension and preeclampsia. Obstet Gynecol 1998; 92: 1005-11.

http://dx.doi.org/10.1097/00006250-19981200000023

12. Giguere Y, Charland M, Bujold E, et al.. Combining biochemical and ultrasonographic markers in predicting preeclampsia: A systematic review. Clin Chem 2010; 56, 361-75. http://dx.doi.org/10.1373/clinchem.2009.134080

13. Poon LC, Kametas NA, Maiz N et al. Firsttrimester prediction of hypertensive disorders in pregnancy. Hypertension 2009; 53, 812-8. http://dx.doi.org/10.1161/HYPERTENSIONAHA. 108.127977

14. Haynes RBKastner M,Wilczynski NL, Hedges T. Developing optimal search strategies for detecting clinically sound and relevant causation studies in embase. BMC Med Inform Decis Mak 2005; $5: 8$. http://dx.doi.org/10.1186/1472-6947-5-8

15. Haynes RB,Wilczynski N, McKibbon KA et al. Developing optimal search strategies for detecting clinically sound studies in medline. J Am Med Inform Assoc 1994; 1: 447-58. http://dx.doi.org/10.1136/jamia.1994.95153434 
16. Chapman AB, Abraham WT, Zamudio S, et al. Temporal relationships between hormonal and hemodynamic changes in early human pregnancy. Kidney Int 1998; 54, 2056-63.

http://dx.doi.org/10.1046/j.1523-1755.1998.00217.x

17. Hunter S, Robson SC. Adaptation of the maternal heart in pregnancy. Br Heart J 1992; 68: 540-3. http://dx.doi.org/10.1136/hrt.68.12.540

18. Williams DJ, Vallance PJ, NeildGH et al. Nitric oxide-mediated vasodilation in human pregnancy. Am J Physiol 1997; 272: H748-52.

19. Brown MA, Gallery ED. Volume homeostasis in normal pregnancy and pre-eclampsia: Physiology and clinical implications. Baillieres Clin Obstet Gynaecol 1994; 8: 287-310. http://dx.doi.org/10.1016/S0950-3552(05)80322-0

20. Moran P, Lindheimer MD, Davison JM. The renal response to preeclampsia. Semin Nephrol 2004; 24: 588-95.

http://dx.doi.org/10.1016/j.semnephrol.2004.07.008

21. Carruth JE, Mivis SB, Brogan DR, Wenger NK. The electrocardiogram in normal pregnancy. Am Heart J 1981; 10:, 1075-8. http://dx.doi.org/10.1016/0002-8703(81)90497-X

22. Angeli F, Angeli E,Verdecchia P. Electrocardiographic changes in hypertensive disorders of pregnancy. Hypertens Res 2014; 37: 973-5.

http://dx.doi.org/10.1038/hr.2014.128

23. Akinwusi PO, Oboro VO, Adebayo RA et al. Cardiovascular and electrocardiographic changes in nigerians with a normal pregnancy. Cardiovasc J Afr 2011; 22: 71-5. http://dx.doi.org/10.5830/CVJA-2010-043

24. Boyle DM, Lloyd-Jones RL. The electrocardiographic ST segment in pregnancy. J Obstet Gynaecol Br Commonw 1966;73: 986-7. http://dx.doi.org/10.1111/j.1471-0528.1966.tb06125.x

25. Grand A, Rigaud-Morel N, Drouin B et al..Electrocardiographic changes induced by pregnancy in healthy women. Arch Mal Coeur Vaiss 1983; 76: 77-86.

26. Gregorini L,Valentini R, Lo Cicero G et al. Electrocardiographic and vectorcardiographic modifications during pregnancy and post partum. Boll Soc Ital Cardiol 1976; 21: 2049-54.

27. Halphen C,Leguludec D,Valent R,Haiat R. Electrocardiographic study of left ventricular performance in normal pregnancy. Arch Mal Coeur Vaiss 1984; 77: 212-7.

28. Illanes A, Droguett A, Fuentealba A. Electrocardiographic studies on normal pregnancy. Rev Med Chil 1953; 81: 152-9.

29. Wenger NK, Hurst JW, Strozier VN. Electrocardiographic changes in pregnancy. Am J Cardiol 1964; 13: 774-8. http://dx.doi.org/10.1016/0002-9149(64)90426-6

30. BaumertM,Seeck A, Faber R, et al., Longitudinal changes in qt interval variability and rate adaptation in pregnancies with normal and abnormal uterine perfusion. Hypertens Res 2010, 33: 555-60.

http://dx.doi.org/10.1038/hr.2010.30

31. Isezuo SA,Ekele BA. Eclampsia and abnormal QTc. West Afr J Med 2004; 23: 123-7. http://dx.doi.org/10.4314/wajm.v23i2.28102

32. Raffaelli R, Prioli MA, Parissone F et al. Preeclampsia: Evidence of altered ventricular repolarization by standard ECG parameters and QT dispersion. Hypertens Res 2014; 37: 984-8.

http://dx.doi.org/10.1038/hr.2014.102

33. Higham PD, Campbell RW. QT dispersion. Br Heart J 1994; 71: 508-10.

http://dx.doi.org/10.1136/hrt.71.6.508

34. Bazett, H. An analysis of the time-relations of electrocardiograms. Heart 1920; 7: 353-70.

35. Verdecchia P, Angeli F, Mazzotta G et al. Simplifying the ECG Diagnosis of Left Ventricular Hypertrophy Curr Cardiovasc Risk Rep2011; 5:1-4.

36. Prineas R, Crow R, Blackburn H. The Minnesota code manual of electrocardiographic findings: Standards and procedures for measurement and classification. Littleton: John Wright-PSG. 1982.

37. Tarazi RC, Miller A, Frohlich ED, Dustan HP. Electrocardiographic changes reflecting left atrial 
abnormality in hypertension. Circulation 1966; 34: 818-2.

http://dx.doi.org/10.1161/01.CIR.34.5.818

38. Munuswamy K, Alpert MA, Martin RH, et al.. Sensitivity and specificity of commonly used electrocardiographic criteria for left atrial enlargement determined by m-mode echocardiography. Am J Cardiol 1984; 53: 829-32. http://dx.doi.org/10.1016/0002-9149(84)90413-2

39. Lenfant C. Working group report on high blood pressure in pregnancy. J Clin Hypertens (Greenwich) 2001; 3: 75-88.

http://dx.doi.org/10.1111/j.1524-6175.2001.00458.x

40. Lindheimer MD, Taler SJ, Cunningham FG. Hypertension in pregnancy. J Am Soc Hypertens 2008; 4: 68-78.

http://dx.doi.org/10.1016/j.jash.2010.03.002

41. Frohlich ED, Tarazi RC, Dustan HP. Clinicalphysiological correlations in the development of hypertensive heart disease. Circulation 1971; 44: 446-55.

http://dx.doi.org/10.1161/01.CIR.44.3.446

42. Miller JT, O'Rourke RA, Crawford MH. Left atrial enlargement: An early sign of hypertensive heart disease. Am Heart J 1988; 116: 1048-51. http://dx.doi.org/10.1016/0002-8703(88)90158-5

43. Dunn FG,Chandraratna P, deCarvalho JG et al. Pathophysiologic assessment of hypertensive heart disease with echocardiography. Am J Cardiol 1977; 39: 789-95. http://dx.doi.org/10.1016/S0002-9149(77)80028-3

44. Pearson AC, Gudipati C, Nagelhout D et al. Echocardiographic evaluation of cardiac structure and function in elderly subjects with isolated systolic hypertension. J Am Coll Cardiol 1991; 17: 422-30. http://dx.doi.org/10.1016/S0735-1097(10)80109-3

45. Vaziri SM, Larson MG, Lauer MS et al. Influence of blood pressure on left atrial size. The Framingham Heart Study. Hypertension 1995; 25: 1155-60.

http://dx.doi.org/10.1161/01.HYP.25.6.1155

46. Lindheimer MD, Katz AI. Sodium and diuretics in pregnancy. N Engl J Med 1973; 288: 891-4. http://dx.doi.org/10.1056/NEJM197304262881706
47. Myers BD, Peterson C, Molina C et al. Role of cardiac atria in the human renal response to changing plasma volume. Am J Physiol 1988; 254: F562-73.

48. Focaccio A, Volpe M, Ambrosio G et al. Angiotensin II directly stimulates release of atrial natriuretic factor in isolated rabbit hearts.Circulation 1993; 87:192:9. http://dx.doi.org/10.1161/01.CIR.87.1.192

49. Lund CJ, Donovan JC. Blood volume during pregnancy. Significance of plasma and red cell volumes. Am J Obstet Gynecol 1967;98,:394-403. http://dx.doi.org/10.1016/0002-9378(67)90160-3

50. Bernstein IM, Ziegler W, Badger GJ. Plasma volume expansion in early pregnancy. Obstet Gynecol 2001;97: 669-72.

http://dx.doi.org/10.1097/00006250-20010500000005

51. Nade, AS,Ballermann BJ, Anderson S, Brenner BM. Interrelationships among atrial peptides, renin, and blood volume in pregnant rats. Am J Physiol 1988; 254: R793-800.

52. Schrier RW. Pathogenesis of sodium and water retention in high-output and low-output cardiac failure, nephrotic syndrome, cirrhosis, and pregnancy (2). N Engl J Med 1988; 319: 1127-34. http://dx.doi.org/10.1056/NEJM198810273191705

53. Bond AL, August P, Druzin ML et al. Atrial natriuretic factor in normal and hypertensive pregnancy. Am J Obstet Gynecol 1989; 160: 1112-6. http://dx.doi.org/10.1159/000293156

54. Mikkelsen AL,Schutten G, Asping U, Schutten, HJ. Plasma concentration of atrial natriuretic peptide in normal pregnant women and in pregnant women with preeclampsia. Gynecol Obstet Invest 1991; 31: 192-5. http://dx.doi.org/10.1159/000293156

55. Sumioki H, Shimokawa H, Miyamoto $S$ et al. Circadian variations of plasma atrial natriuretic peptide in four types of hypertensive disorder during pregnancy. Br J Obstet Gynaecol 1989; 96: 922-7.

http://dx.doi.org/10.1111/j.1471-0528.1989.tb03346.x

56. Brown MA, Gallery ED, Ross MR, Esber RP. Sodium excretion in normal and hypertensive 
pregnancy: A prospective study. Am J Obstet Gynecol 1988; 159: 297-307. http://dx.doi.org/10.1016/S0002-9378(88)80071-1

57. Hsueh WA, Luetscher JA, Carlson EJ, et al.Changes in active and inactive renin throughout pregnancy. J Clin Endocrinol Metab 1982; 54: 1010-6.

http://dx.doi.org/10.1210/jcem-54-5-1010

58. Merrill DC, Karoly M, Chen Ket al. Angiotensin(1-7) in normal and preeclamptic pregnancy. Endocrine 2002; 18: 239-45.

http://dx.doi.org/10.1385/ENDO:18:3:239

59. Acar K, Beyazit $Y$, Sucak A et al. Alterations in the 'local umbilical cord blood renin-angiotensin system' during pre-eclampsia. Acta Obstet Gynecol Scand 2007; 86: 1193-9.

http://dx.doi.org/10.1080/00016340701552434

60. Benedetto C, Marozio L, Ciccone G et al. Synergistic effect of renin-angiotensin system and nitric oxide synthase genes polymorphisms in pre-eclampsia. Acta Obstet Gynecol Scand 2007; 86: 678-82.

http://dx.doi.org/10.1080/00016340701415269

61. Brown MA, Reiter L, Rodger A, Whitworth JA. Impaired renin stimulation in pre-eclampsia. Clin Sci (Lond) 1994; 86: 575-81. http://dx.doi.org/10.1042/cs0860575

62. Brown MA, Wang J, Whitworth JA. The reninangiotensin-aldosterone system in preeclampsia. Clin Exp Hypertens 1997;19: 713-26. http://dx.doi.org/10.3109/10641969709083181

63. Herse F, Dechend R, Harsem NK et al. Dysregulation of the circulating and tissue-based renin-angiotensin system in preeclampsia. Hypertension 2007;49: 604-11. http://dx.doi.org/10.1161/01.HYP.0000257797.492 89.71

64. Mistry HD, Kurlak LO, Broughton Pipkin F. The placental renin-angiotensin system and oxidative stress in pre-eclampsia. Placenta 2013; 34:182-6. http://dx.doi.org/10.1016/j.placenta.2012.11.027

65. Pedersen EB, Rasmussen AB,Johannesen $\mathrm{P}$ et al. The renin-aldosterone system in pre-eclampsia, essential and transient hypertension during pregnancy, and normotensive pregnant and nonpregnant control subjects. ActaEndocrinol (Copenh) 1982; 101: 273-80.

http://dx.doi.org/10.1530/acta.0.1010273

66. Raty R, Koskinen P, Alanen A, et al. Prediction of pre-eclampsia with maternal mid-trimester total renin, inhibin a, afp and free beta-hcg levels. Prenat Diagn 1999; 19: 122-7. http://dx.doi.org/10.1002/(SICI)10970223(199902)19:2<122::AID-PD491>3.0.CO;2-R

67. Verdonk K,Visser W, Van Den Meiracker AH, Danser $\mathrm{AH}$. The renin-angiotensin-aldosterone system in pre-eclampsia: The delicate balance between good and bad. ClinSci (Lond) 2014; 126: $537-44$.

http://dx.doi.org/10.1042/CS20130455 


\title{
Modeli za predviđanje rizika od hipertenzivnih poremećaja u trudnoći: uloga 12-kanalne elektrokardiografije
}

\author{
Fabio Angeli ${ }^{1}$, Enrica Angeli ${ }^{2}$, Antonella D' Antonio ${ }^{1}$, Cristina Poltronieri ${ }^{1}$, Giuseppe Ambrosio ${ }^{1}$ \\ ${ }^{1}$ Odeljenje za kardiologiju, Univerzitet u Peruđi Medicinski fakultet, Peruđa, Italija \\ ${ }^{2}$ Odeljenje za ginekologiju i akušerstvo, Bolnica San G.Battista, Foligno, Italy
}

\section{SAŽETAK}

Hipertenzivni poremećaji predstavljaju najčešće medicinske komplikacije u toku trudnoće i javljaju se u $6 \%$ do $8 \%$ gestacija. Mogu dovesti do ozbiljnih poremećaja kod majke i fetusa.

Nekoliko opservacionih studija je pokazalo da se težina, sistolni i dijastolni pritisak, izmereni na pregledu pre 16. gestacijske nedelje, mogu koristiti za određivanje rizika od razvoja hipertenzivnih poremećaja u toku trudnoće.

Međutim, nedavno su za potencijalne prediktore hipertenzivnih poremećaja predloženi neki drugi markeri. U ovom kontekstu, izvesne elektrokardiografske promene su se pokazale kao veoma značajne u detaljnijem određivanju rizika. Naročito su promene tokom trudnoće u QT intervalu i morfologiji $P$ talasa poboljšale tačnost multivarijabilnih modela predviđanja hipertenzivnih poremećaja. Na primer, izgleda da je prisustvo abnormalnosti leve komore na EKG-u povezano sa značajnim povećanjem rizika od razvoja hipertenzivnih poremećaja, i kada su uključene u multivarijabilni model, uzimajući u obzir neke osobine majke, mogu da naprave razliku između žena kod kojih će se razviti hipetenzivni poremećaji i onih koje će ostati normotenzivne. Ovaj model za predviđanje je takođe mogao da identifikuje trudnice kod kojih je postojao povećani rizik od komplikacija $\mathbf{u}$ fetusu i neonatusu.

Cilj ovog preglednog rada bio je da prikaže dostupne podatke koji pružaju dokaze da specifični EKG obrasci koji se beleže u ranom toku trudnoće mogu da imaju klinički značaj za predviđanje hipertenzivnih poremećaja.

Ključne reči: hipertenzivni poremećaji, trudnoća, modeli za predviđanje rizika, eklampsija, krvni pritisak, elektrokardiografija 